\title{
Local administration of submicron particle paclitaxel to solid carcinomas induces direct cytotoxicity and immune-mediated tumoricidal effects without local or systemic toxicity: preclinical and clinical studies
}

\author{
Shelagh Verco ${ }^{1}$. Holly Maulhardt ${ }^{1} \cdot$ Michael Baltezor $^{2} \cdot$ Emily Williams $^{1} \cdot$ Marc lacobucci $^{3,4}$ - Alison Wendt ${ }^{1}$. \\ James Verco ${ }^{1} \cdot$ Alyson Marin ${ }^{1} \cdot$ Sam Campbell ${ }^{2,3} \cdot$ Paul Dorman $^{3,4} \cdot$ Gere diZerega $^{1,3}$
}

Accepted: 12 October 2020 / Published online: 6 November 2020

(C) The Author(s) 2020

\begin{abstract}
This report describes local administration of submicron particle paclitaxel (SPP) (NanoPac $($ : 800-nm-sized particles with high relative surface area with each particle containing $~ 2$ billion molecules of paclitaxel) in preclinical models and clinical trials evaluating treatment of carcinomas. Paclitaxel is active in the treatment of epithelial solid tumors including ovarian, peritoneal, pancreatic, breast, esophageal, prostate, and non-small cell lung cancer. SPP has been delivered directly to solid tumors, where the particles are retained and continuously release the drug, exposing primary tumors to high, therapeutic levels of paclitaxel for several weeks. As a result, tumor cell death shifts from primarily apoptosis to both apoptosis and necroptosis. Direct local tumoricidal effects of paclitaxel, as well as stimulation of innate and adaptive immune responses, contribute to antineoplastic effects. Local administration of SPP may facilitate tumor response to systemically administered chemotherapy, targeted therapy, or immunotherapy without contributing to systemic toxicity. Results of preclinical and clinical investigations described here suggest that local administration of SPP achieves clinical benefit with negligible toxicity and may complement standard treatments for metastatic disease.
\end{abstract}

Keyword NanoDoce $\cdot$ NanoPac $\cdot$ Ovarian cancer $\cdot$ Pancreatic cancer $\cdot$ Pancreatic cysts $\cdot$ Prostate cancer $\cdot$ Lung cancer

\section{Introduction}

Paclitaxel is a high molecular weight, highly protein bound, hydrophobic molecule, which limits its access to tumor cells. IV administration of paclitaxel achieves relatively low levels of drug at the tumor for a short period of time, resulting in intermittent tumor cell exposure to drug resulting in death that is typically apoptotic and may allow for some tumor cell

Gere diZerega

gere.dizerega@usbiotest.com

1 US Biotest, Inc. 231 Bonetti Drive, Suite 240, San Luis Obispo, CA 93401,, USA

2 CritiTech Particle Engineering Solutions, LLC, 1849 E 1450 Road, Lawrence, KS 66044,, USA

3 NanOlogy, LLC, 3909 Hulen Street, Fort Worth, TX 76107,, USA

4 DFB Pharmaceuticals, Inc, 3909 Hulen Street, Fort Worth, TX 76107,, USA survival, division, and/or mutation potentially resulting in paclitaxel resistance.

Local treatment of solid tumors by systemic therapies has the potential to increase tumoricidal effects without increasing systemic toxicity. It has long been hypothesized that local, sustained tumor treatment would make the drug available to tumor cells over multiple cell-division cycles, resulting in tumoricidal benefits without compromising the patient's quality of life [1]. Various particle-based drug delivery systems are being developed for treatment of cancer $[2,3]$. However, success of many systems is limited by ineffective delivery to tumor sites as well as abbreviated drug residence due, in part, to the clearance of particles by the immune system [4].

In order to address the limitations of IV treatment modalities, submicron particles of paclitaxel (SPP, Nano$\mathrm{Pac} \AA$, NanOlogy, Ft Worth, TX), with a mean particle size of $\sim 800 \mathrm{~nm}$ (containing approximately 2 billion paclitaxel molecules each) with a high surface area to facilitate 
molecule release, were developed to allow for suspension in an aqueous media [5]. These aqueous suspensions of SPP allow for various routes of local administration including inhalation (IH) via nebulizer, intraperitoneal (IP) delivery, or intratumoral (IT) injection.

This review will describe the therapeutic potential of SPP for treatment of various solid tumors and associated clinical trials, all of which demonstrate clinical utility in small Phase $1 / 2$ studies (Table 1 ). We will provide early preclinical and clinical evidence that tumor and immune responses to paclitaxel released from locally administered SPP are different than responses to paclitaxel delivered intravenously (IV). These findings support the conclusion that SPP may offer an important addition to cancer therapy without adding clinically significant local or systemic toxicity.

\section{Preparation of submicron taxane particles}

Precipitation with compressed antisolvents (PCA) is a nonsolvent process by which a drug substance dissolved in an organic solvent is precipitated in a supercritical antisolvent. Baltezor et al. [5] described a method by which paclitaxel dissolved in acetone processed with supercritical $\mathrm{CO}_{2}$ created SPP with a number-weighted mean particle size ranging from 0.670 to $0.861 \mu \mathrm{m}$ with a specific surface area greater than $22 \mathrm{~m}^{2} / \mathrm{g}$ and a bulk density between 0.05 and $0.15 \mathrm{~g} / \mathrm{cm}^{3}$ (Fig. 1; CritiTech, Lawrence, KS). The volume-weighted mean particle size distribution for this product ranged from 2.8 to $3.5 \mu \mathrm{m}$ and matches the size of the particles found by scanning electron microscopy (SEM). Figure $2 \mathrm{a}$ and $\mathrm{b}$ is SEM photomicrographs of the unprocessed and PCA processed paclitaxel. They reveal morphological differences

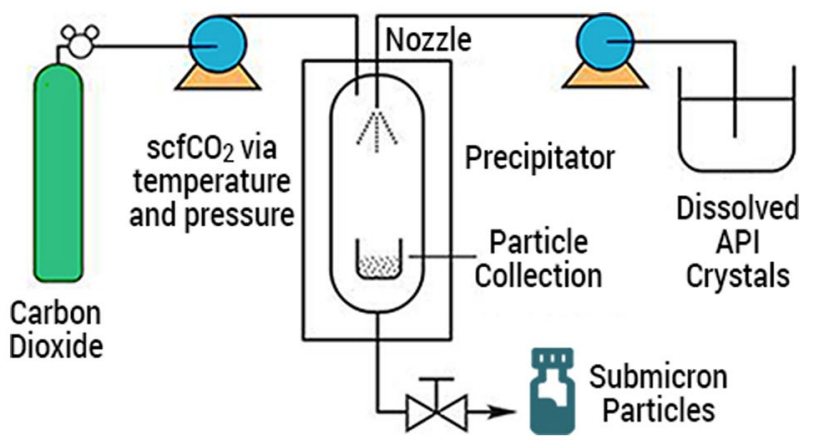

Fig. 1 Schematic of continuous manufacturing process for submicron particle paclitaxel. Supercritical carbon dioxide $\left(>72.8 \mathrm{bar},>31{ }^{\circ} \mathrm{C}\right)$ $\left(\mathrm{ScCO}_{2}\right)$ is freely soluble with many organic solvents but insoluble with paclitaxel. Paclitaxel dissolved in organic solvent is sonicated into small droplets and rapidly exposed to $\mathrm{scCO}_{2}$, which strips away the solvent and precipitates the paclitaxel as small particles. These small, stable, flowable particles are captured in a collection chamber and later filled in powder form into vials

between unprocessed and PCA-processed particles. Unprocessed paclitaxel crystals were rod-shaped, thicker, and clumped together resulting in a large size variability. The PCA-processed SPP were much thinner, highly irregular shaped particles with large open areas between particles.

The SPP particles had an increased specific surface area (SSA) which is equivalent to much smaller particles. The increased SSA enhances the release rate of drug from the particles. The irregular shape of the particles is thought to result in interlocking between particles, causing them to function as if they were even larger. We theorize these particles are large enough to avoid being removed by blood flow or by phagocytosis and are retained in tumors,

Table 1 Clinical trials of NanoPac ${ }^{\circledR}$

\begin{tabular}{|c|c|c|c|c|}
\hline Study ID & NCT number & Study title & Study start & Study status ${ }^{\mathrm{a}}$ \\
\hline HSC\#1114 & NCT00666991 & $\begin{array}{l}\text { Pharmacokinetic, safety and efficacy study of nanoparticle paclitaxel in } \\
\text { patients with peritoneal cancers }\end{array}$ & July 2008 & Completed \\
\hline NANOPAC-2016-01 & NCT03029585 & $\begin{array}{l}\text { Phase II study of four dose levels of intraperitoneal NanoPac Plus IV } \\
\text { carboplatin and paclitaxel in patients with epithelial ovarian cancer } \\
\text { undergoing cytoreductive surgery }\end{array}$ & April 2017 & Completed \\
\hline NANOPAC-2016-02 & NCT03077659 & $\begin{array}{l}\text { Phase IIa dose escalation trial of NanoPac focal therapy for prostate } \\
\text { cancer in subjects undergoing radical prostatectomy }\end{array}$ & September 2017 & Completed \\
\hline NANOPAC-2017-01 & NCT03188991 & $\begin{array}{l}\text { A trial evaluating escalating doses and the safety of intracystic injection } \\
\text { of NanoPac in subjects with mucinous cystic pancreatic neoplasms }\end{array}$ & September 2017 & Completed \\
\hline NANOPAC-2016-05 & NCT03077685 & $\begin{array}{l}\text { Phase IIa trial evaluating the safety of intratumoral injection of NanoPac } \\
\text { in subjects with locally advanced pancreatic adenocarcinoma }\end{array}$ & December 2017 & Ongoing \\
\hline NANOPAC-2019-01 & NCT04221828 & $\begin{array}{l}\text { Phase } 2 \text { trial of NanoPac focal therapy for prostate cancer in subjects } \\
\text { undergoing radical prostatectomy }\end{array}$ & July 2020 & Recruiting \\
\hline NANOPAC-2020-01 & NCT04314895 & $\begin{array}{l}\text { Phase } 2 \text { trial evaluating the safety and tolerability of intratumoral injec- } \\
\text { tions of NanoPac® with standard of care therapy in subjects with lung } \\
\text { cancer }\end{array}$ & September 2020 & Recruiting \\
\hline
\end{tabular}

\footnotetext{
${ }^{\mathrm{a}}=$ Study status current as of 5 October 2020
} 
Fig. 2 (a) Paclitaxel drug substance and (b) Paclitaxel drug substance precipitated with compressed antisolvents results in particles of paclitaxel with a specific surface area $>22 \mathrm{~m}^{2} /$ gm with a bulk density between 0.05 and $0.15 \mathrm{gm} / \mathrm{cm}^{3}$
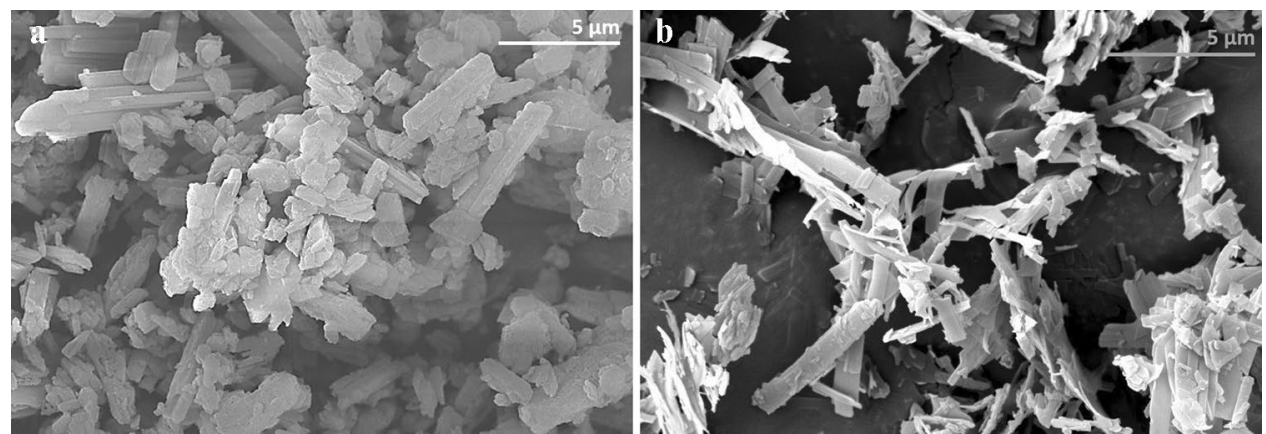

creating a sustained drug release depot while minimally contributing to systemic paclitaxel levels. Parallel PCA processes can also be employed to generate submicron particle docetaxel (SPD). When administered to tumors as an aqueous suspension, the PCA particles release paclitaxel $[6,7]$ or docetaxel $[8]$ into the surrounding tumor microenvironment (TME) at tumoricidal levels (Fig. 3).

These large agglomerated particles with the high SSA and the low bulk density are also excellent candidates for enhancing pulmonary drug delivery. The mass median aerodynamic diameter (MMAD) of PCA particles is typically in the range of 2 to $4 \mu \mathrm{m}$. However, the physical size of the particles or agglomerates of the particles is $>5 \mu \mathrm{m}$ which is large enough to inhibit removal from the lungs by phagocytosis. We have observed that PCA-produced particles provide much longer lung residence times [6].

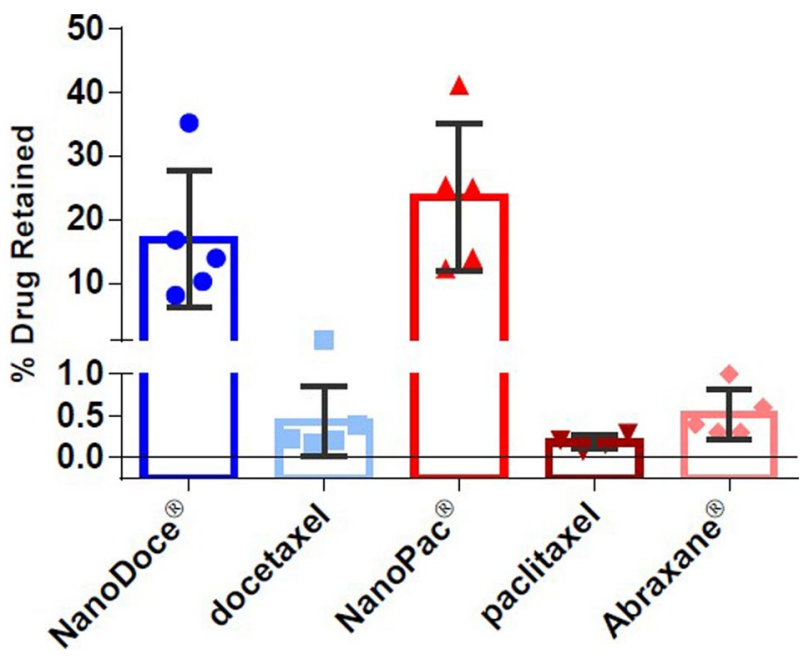

Fig. 3 Percent drug retained in MDA-MB-231 tumors. Formulations $(5 \mathrm{mg} / \mathrm{mL}$ each) were administered as $0.05 \mathrm{~mL}$ direct injections into MDA-MB-231 tumors implanted on the flanks of female BALB/c mice ( $n=4$ or 5 per group), and tumor tissues were collected 5 days later. The percent of drug retained was calculated based on the concentration of drug detected (ng/g of tumor) and tumor weight. Group mean docetaxel (blue bars) and paclitaxel percent (red bars) as well as individual tumor percent (symbols) are plotted; error bars $= \pm 1 \mathrm{SD}$
The PCA process is adjustable to allow for particle engineering of a specific drug to create particles with the most desirable characteristics for an intended delivery method. Processing variables of the solvent, the concentration of drug in the solvent, the spray rate of the drug solution, the intensity of the sonic energy as well as the flow rate, and pressure of the supercritical $\mathrm{CO}_{2}$ are examples. Once defined and controlled, the PCA process is reproducible with high yields (> 95\%) and low residual solvent.

Prior to the start of the Phase 2 clinical trials, 3 batches of SPP were manufactured under full GMP conditions using continuous process of approximately $36 \mathrm{~h}$ each. The batches shown in Table 2 were used for the Phase 2 clinical supplies and for providing ICH compliant stability data for SPP. Table 2 shows the results at $T_{0}$ and after 48 months storage at $25^{\circ} \mathrm{C} 60 \% \mathrm{RH}$ in $60 \mathrm{ml}$ sterile glass vials. The data demonstrates the consistency and excellent stability of the 3 batches. The batches have been monitored with Xray powder diffraction (XPRD) and differential scanning calorimetry (DSC) to confirm that there have been no changes in the crystalline form of the particles. All three batches had an untapped bulk density of $\sim 0.08 \mathrm{~g} / \mathrm{cm}^{3}$. The particle size by volume (Dv50) shown in Table 2 was found to be a critical parameter in the understanding of the relationship between the particle size, the bulk density and the high specific surface area of the particles. We are still in the process of finalizing an in vitro dissolution test, but we have found that the specific surface area of the particles has a direct linear correlation with the dissolution results for the particles.

\section{Preclinical studies}

\section{Lung cancer}

Efficacy of IV paclitaxel in the treatment of lung cancer is limited by its concentration and duration of tumor exposure. Alternate routes of administration have been evaluated [9] including IH and IT injections by bronchoscopy [10]. Studies of IH paclitaxel demonstrated preliminary proof-of-efficacy in non-small cell lung cancer (NSCLC) 
Table 2 Results of 3 GMP

NanoPac ${ }^{\circledR}$ batches used for Phase 2 clinical studies and ICH compliant stability

\begin{tabular}{|c|c|c|c|c|c|c|c|}
\hline \multirow{2}{*}{$\begin{array}{l}\text { NanoPac® } \\
\text { Lot number }\end{array}$} & \multicolumn{2}{|c|}{ Assay (\%) } & \multicolumn{2}{|c|}{ Particle size $($ Dn50) $(\mu)$} & \multirow{2}{*}{$\begin{array}{l}\text { Particle size } \\
(\text { Dv50) }(\mu) \\
48 \text { months }\end{array}$} & \multicolumn{2}{|c|}{ Surface area $\left(\mathrm{m}^{2} / \mathrm{g}\right)$} \\
\hline & $T_{0}$ & 48 months & $T_{0}$ & 48 months & & $T_{0}$ & 48 months \\
\hline STV090915 & 100.4 & 98.2 & 0.79 & 0.89 & 2.86 & 29.9 & 28.4 \\
\hline STV093015 & 98.2 & 98.2 & 0.76 & 0.89 & 3.22 & 29.1 & 26.1 \\
\hline STV100715 & 98 & 98 & 0.83 & 0.85 & 3.2 & 27.9 & 25.9 \\
\hline
\end{tabular}

preclinical models [11]. Inhaled chemotherapy could theoretically deliver substantial doses directly to the pulmonary parenchyma and adjoining airways while avoiding additive toxic exposure to nontarget organs. Historically, however, achieving sustained pulmonary exposure through $\mathrm{IH}$ was limited by poor retention of drug within the pulmonary tissues due to clearance mechanisms such as diffusion across the alveolar-capillary membranes, the mucociliary "escalator" removing material to the gastrointestinal tract, and phagocytosis by alveolar macrophages and dendritic cells, as well as lymphatic drainage. To address these challenges, IH of nebulized SPP was evaluated. Following IH of nebulized SPP, substantial levels of paclitaxel in the lung were achieved for at least 2-week post-administration (Fig. 4), confirming the increased local retention and efficacy of IH SPP $[6,7]$.

In NIH-nru nude rats orthotopically implanted with Calu-3 cells (human lung adenocarcinoma) treatment with inhaled SPP resulted in tumor growth inhibition, regression, and infiltration [7]. In some lung samples, no residual tumor was detected upon histopathological examination; scattered,

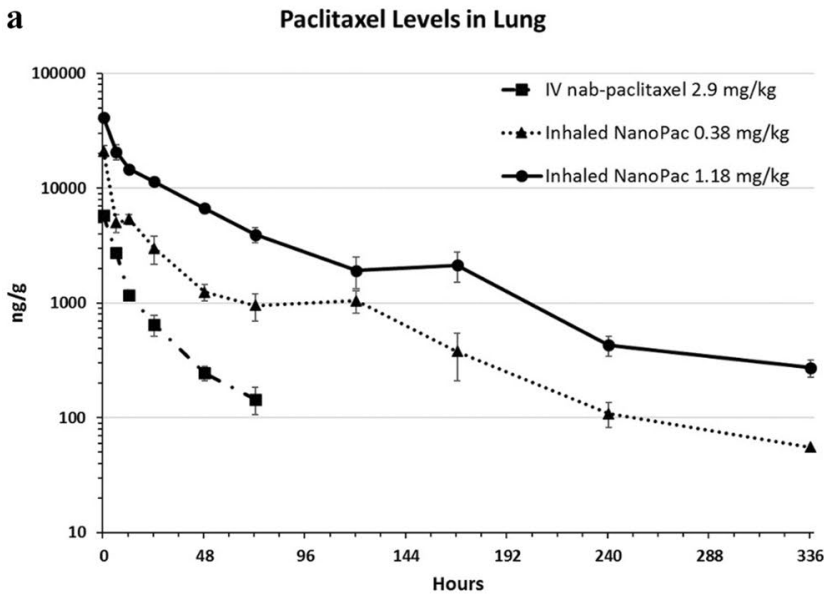

Fig. 4 Paclitaxel levels in lung (a) and plasma (b) after inhaled NanoPac treatment. Male Sprague-Dawley rats (6-8 weeks old) were administered paclitaxel on a single occasion in one of three treatment arms $(n=30$ each): inhaled submicron particle paclitaxel in a noseonly exposure at a low-dose of $0.38 \mathrm{mg} / \mathrm{kg}$ or a high dose of $1.18 \mathrm{mg} /$ $\mathrm{kg}$, or intravenous nab-paclitaxel administered via tail vein injection at $2.9 \mathrm{mg} / \mathrm{kg}$. Three animals from each arm were sacrificed at $0.5,6$, $12,24,48,72,120,168,240$, and $336 \mathrm{~h}$ post exposure for lung tissue small fibrotic nodules, and stroma replacing areas presumed to have once contained tumor was observed. Tumor regression and eradication were accompanied by a robust immune cell infiltrate of lymphocytes and macrophages into the tumor spaces. Since these animals were athymic and thus deficient in $\mathrm{T}$ cells, any immune-mediated tumoricidal affect would have been due to macrophage infiltration and primarily antibody-dependent, cell-mediated cytotoxicity (ADCC) or antibody dependent, and cell-mediated phagocytosis (ADCP). Paclitaxel is known to enhance ADCC [12]. These two anti-tumor responses depend on both the presence of antibodies against the tumor and the presence of immune effector cells. Immunohistochemical staining (IHC) of lung tissue showed an increase in CD11b + immune cell infiltration in lung samples following IH SPP. Some of the bronchus associated lymphoid tissue (BALT) exhibited architecture consistent with active germinal centers within lymphoid follicles (Fig. 5). These findings suggest that persistent paclitaxel release at high concentrations facilitates antigen presentation to the host immune system and that

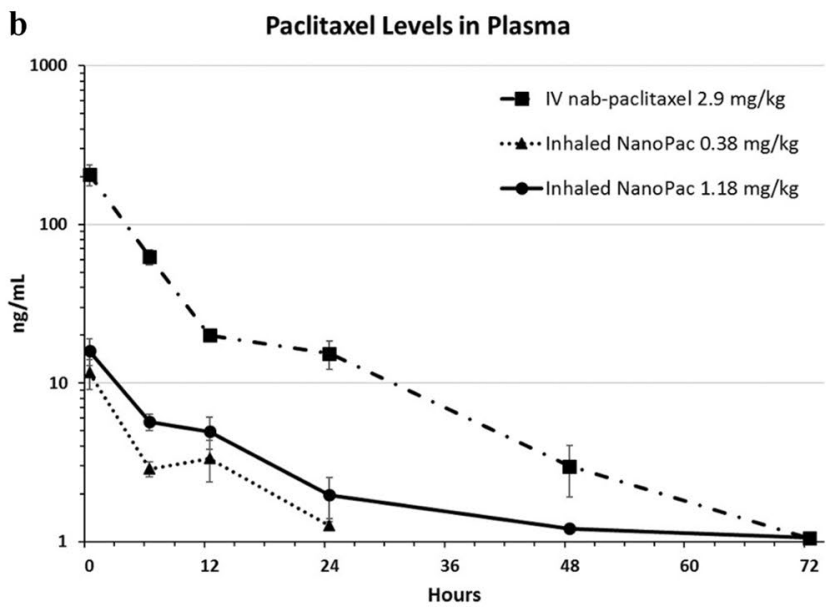

and plasma collections. Lung tissue (a) and plasma (b) were assayed via ultra-performance liquid chromatography tandem mass spectrometry to quantify paclitaxel concentration as a function of time with a lower level of quantification of $50 \mathrm{ng} / \mathrm{g}$ and $1 \mathrm{ng} / \mathrm{mL}$, respectively (mean $\pm 1 \mathrm{SEM}$ ) [6]. Reprinted by permission from Mary Ann Liebert, Inc.: [Mary Ann Liebert] [Journal of Aersol Medicine and Pulmonary] [Pharmacokinetic profile of inhaled submicron particle paclitaxel (NanoPac) in a rodent model, James Verco et al.] [2019] 

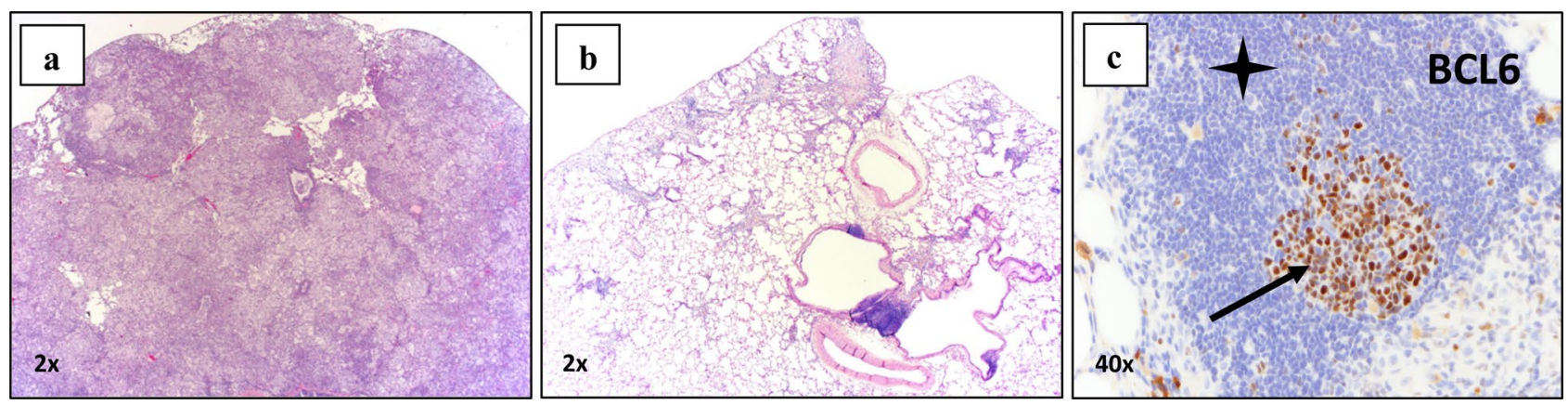

Fig. 5 In an orthotopic nude NIH male rat lung cancer model (Calu3) was treated with inhaled submicron particle paclitaxel twice weekly for 4 weeks at 0.5 and $1.0 \mathrm{mg} / \mathrm{kg}$. All animals survived to their scheduled necropsy and exhibited no adverse clinical observations from treatment. Left lungs were paraffin embedded, serially sectioned and stained for histopathological and immunohistochemical examination. (a) Control group treated with vehicle exhibited unabated tumor growth; (b) inhaled submicron particle paclitaxel groups presented a reduced or absent tumor presence and contained occa-

antigen availability enhances immune cell infiltration into tumor sites.

\section{Genitourinary neoplasms}

Direct IT injection of SPP into xenograft models of human prostate and renal cell carcinoma lines produced regression or eradication of tumors (Fig. 6a,b). Formation of sional areas of residual fibrosis; (c) BCL-6 stained follicles revealed localized B-cells at the germinal center (black arrow) and B-cells in the submicron particle inhaled groups (black star) which reside in the surrounding mantle zone [7]. Reprinted by permission from Mary Ann Liebert, Inc.: [Mary Ann Liebert] [Journal of Aersol Medic ine and Pulmonary Delivery] [Inhaled submicron particle paclitaxel (NanoPac) induces tumor regression and immune cell infiltration in an orthotopic athymic nude rat model of non-small cell lung cancer, James Verco et al.] [2019]

fibrin deposits, presumably from tumor debris, was associated with a robust immune cell infiltrate at the tumor site. In contrast, animals that received IV taxane showed continued tumor growth and modest to no immune cell infiltration $[8,13,14]$. These observations suggest that the response of carcinomas to prolonged exposure to tumoricidal levels of taxanes may involve at least two different mechanisms. First, direct tumor kill by the taxane-induced

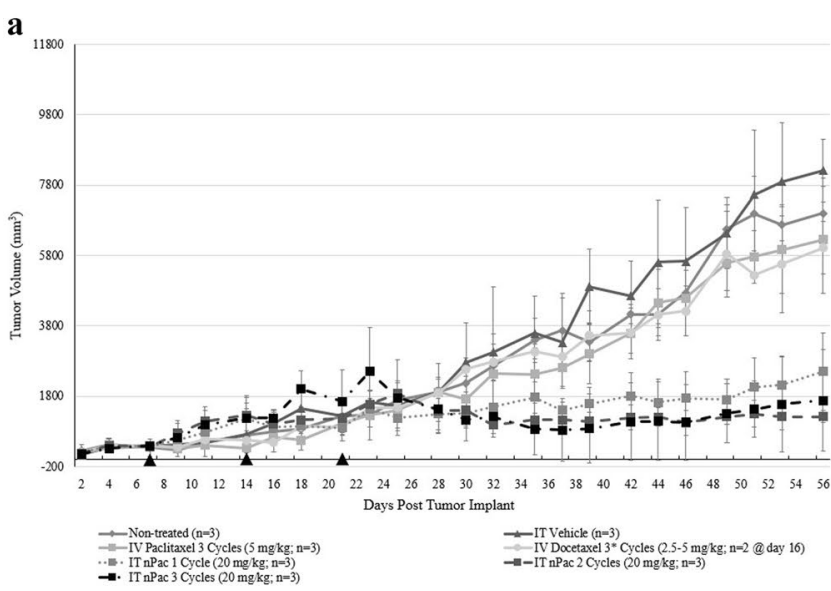

Fig. 6 (a) Mean tumor volume in 786-O renal cancer xenograft in 5-7-week-old female Sprague-Dawley Rag2; Il2 rg (null) rats ( $n=2-3$ animals/group) following IT treatment with submicron particle paclitaxel $(\mathrm{nPac} ; 20 \mathrm{mg} / \mathrm{kg})$. Treatments were initiated seven days after tumor implant and administered weekly for one, two or three cycles (black triangles). Control groups included no treatment, IT vehicle administered on the same schedule as IT submicron particle paclitaxel, IV paclitaxel, or IV docetaxel. * = due to toxicity, following the first cycle the IV docetaxel regimen was modified from 5 to $2.5 \mathrm{mg} / \mathrm{kg}$ for one or two additional cycles. Tumors were meas-

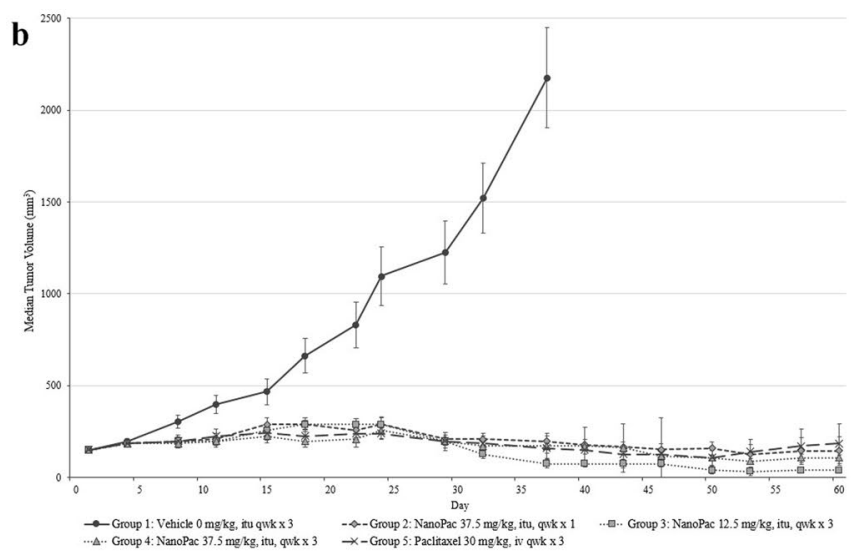

ured with calipers three times weekly for the duration of the study [13]. (b) Median tumor volume in PC-3 prostate cancer xenograft in 11-week-old female $\mathrm{NCr}$ nu/nu mice (Crl:NU(NCr)-Foxn $1^{\text {nu }} ; n=10$ animals/group) following IT treatment with submicron particle paclitaxel (NanoPac; 12.5 to $37.5 \mathrm{mg} / \mathrm{kg}$ ) for 1 or 3 weekly cycles. Control groups included IT vehicle or IV paclitaxel. Treatments were initiated 35 days after tumor implant on Day 1 of the study. Tumors were measured with calipers twice weekly for the duration of the study. [14]. Error bars \pm 1 SDEV 
disruption of mitosis is followed by tumor cell disruption, making neoantigens available and causing antigen spread within the TME. Second, these conditions stimulate immune effector cells to further the local tumoricidal response.

\section{Clinical trials}

\section{Intraperitoneal submicron particle paclitaxel}

The first clinical study of SPP investigated IP administration in patients with carcinoma predominantly confined to the peritoneal cavity who failed prior therapies (NCT00666991, [15]). Twenty-one subjects received SPP via IP ports in doses ranging from 50 to $275 \mathrm{mg} / \mathrm{m}^{2}$. These subjects previously underwent treatments, including IV chemotherapy and debulking surgery. Treatment cycles with IP SPP were 28 days long with one to six cycles administered with the majority of subjects received two cycles. IP administration of SPP did not induce peritonitis nor systemic toxicity typically associated with IV paclitaxel. The peritoneal levels of paclitaxel rose during the 2 days after dosing to concentrations 450-2900 times the peak plasma paclitaxel concentrations and remained elevated throughout the treatment cycle (Fig. 7). Plasma paclitaxel levels remained below $10 \mathrm{ng} / \mathrm{mL}$, well below the systemic toxicity threshold of $40 \mathrm{ng} / \mathrm{mL}$ [16]. Objective tumor response assessed by RECIST 1.0 occurred in five subjects with stable disease and 15 with progressive disease. Six of 21 subjects survived $\geq 1$ year, and three survived $\geq 2$ years despite their advanced disease. Compared with IP administration of nab-paclitaxel in a separate study [17], IP administration of SPP provided higher, sustained

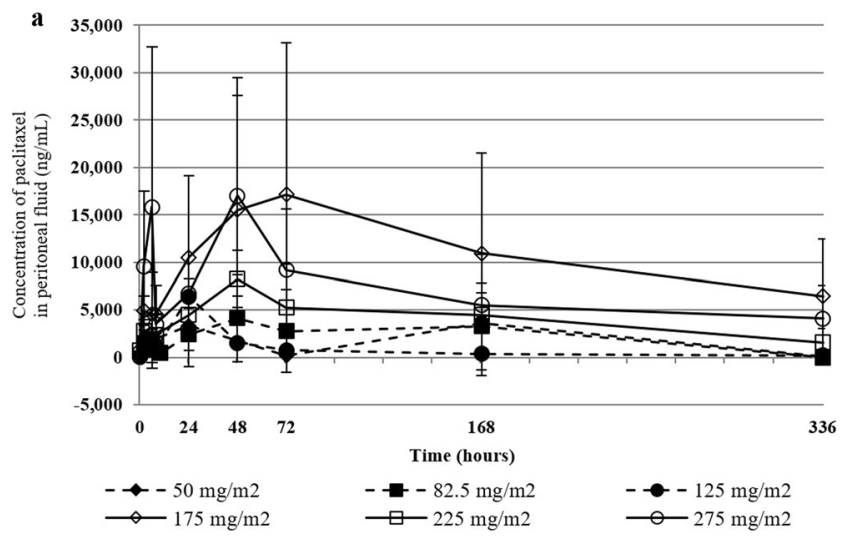

Fig. 7 Peritoneal fluid (a) and plasma (b) paclitaxel concentrations following intraperitoneal administration of submicron particle paclitaxel. Data are averaged over cycles 1 and 2 in subjects with intraperitoneal carcinomas, mostly recurrent ovarian cancer. Mean peritoneal fluid and mean plasma concentrations are presented per dose peritoneal paclitaxel levels with minimal systemic exposure and reduced toxicity [15].

A Phase 2 study in 10 subjects with primary or recurrent ovarian cancer was subsequently conducted to evaluate a single dose of SPP instilled into the peritoneal cavity at the end of debulking surgery (NCT03029585). Subjects also received standard-of-care (SOC), which consisted of IV paclitaxel and carboplatin administered once every 21 days for up to 6 cycles. In the study, $66 \%$ of subjects who received SOC plus a single dose of SPP showed progression-free survival (PFS) over the 12-month study [18].

PK sampling was conducted in seven subjects who received SPP at a dose of $100 \mathrm{mg} / \mathrm{m}^{2}$ and three subjects who received a dose of $200 \mathrm{mg} / \mathrm{m}^{2}$. Blood samples were collected immediately following SPP instillation, prior to each cycle of IV chemotherapy, and at 9- and 12-months post-administration. Plasma paclitaxel concentrations in the $100 \mathrm{mg} / \mathrm{m}^{2}$ dose group were quantifiable $(>25 \mathrm{pg} / \mathrm{mL}$ ) in three of seven subjects prior to Cycle 6 of IV chemotherapy. Quantifiable plasma paclitaxel concentrations were detected in two of three subjects in the $200 \mathrm{mg} / \mathrm{m}^{2}$ dose group prior to the Cycle 3 of IV chemotherapy and in 1 subject at 12 months following SPP instillation. Given that the reported half-life for IV paclitaxel ranges from 9.9 to $16 \mathrm{~h}$ for a 3 -h infusion and 13.1 to $24.6 \mathrm{~h}$ for a 24-h infusion [19], paclitaxel would have cleared systemic circulation by the sixth day following IV administration and thus, not be quantifiable prior to the next cycle of IV paclitaxel. Since plasma paclitaxel concentrations were quantifiable just prior to the 21-day dosing cycle of IV paclitaxel and at the 9- and 12-month follow-up visits, it is likely that SPP acted like a paclitaxel-depot that released drug for an extended period following IP administration.

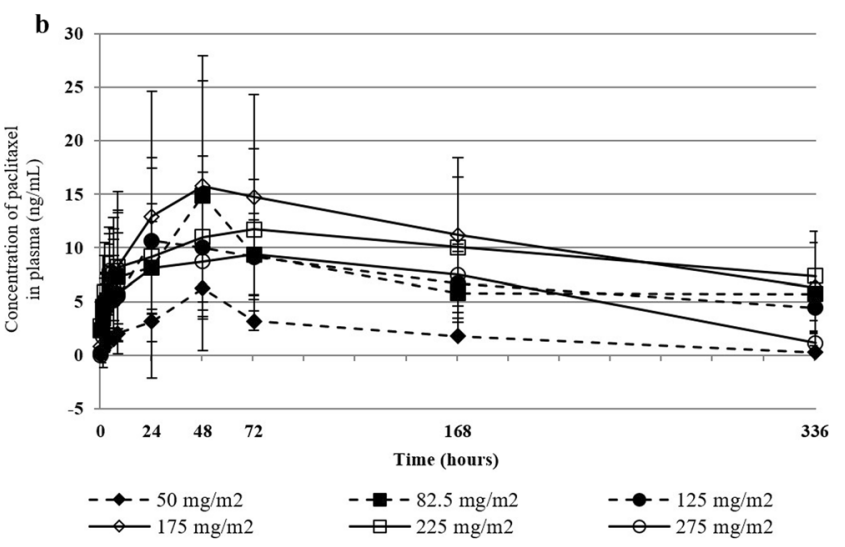

level. Error bars \pm 1 SDEV [15]. Reprinted by permission from Springer Nature: [Springer] [Cancer Chemotherapy and Pharmacolo gy] [A phase I study of intraperitoneal nanoparticulate paclitaxel $\left(\right.$ Nanotax $\left.{ }^{\circledR}\right)$ in patients with peritoneal malignancies, Stephen K. Williamson et al.] [2015] 
These studies support further evaluation of SPP administered into the peritoneal cavity to treat IP carcinomas.

\section{Submicron particle paclitaxel intratumoral injection}

\section{Prostate cancer}

Subjects $(n=16)$ with adenocarcinoma of the prostate and a Gleason score $\geq 7$ were treated via transrectal ultrasound (TRUS)-guided injection of SPP into the index tumor and its lobe that contained the index tumor using multi-parametric magnetic resonance imaging (mpMRI) guidance (NCT03077659). Subjects were allocated to cohorts by a standard $3+3$ dose rising design to receive 6,10 , or $15 \mathrm{mg} /$ $\mathrm{mL} \mathrm{SPP} \mathrm{in} \mathrm{a} \mathrm{volume} \mathrm{equal} \mathrm{to} 20 \%$ of the lobe containing the index lesion, with additional subjects enrolled to an expansion cohort at the $15 \mathrm{mg} / \mathrm{mL}$ dose. A radical prostatectomy was performed 4 weeks after IT SPP treatment. There were no drug-related serious adverse events (SAEs), including no prostatitis, nor dose-limiting toxicities (DLTs), allowing for dose-escalation to the highest concentration $(15 \mathrm{mg} / \mathrm{mL})$. Paclitaxel was detected in all prostate tissue sampled from prostatectomy specimens and in lymph nodes of nine subjects $>30$ days following intraprostatic (ITP) SPP treatment. Percentage of adenocarcinoma in core biopsies decreased between screening and prostatectomy in six subjects and remained unchanged in five. Among seven subjects that received $15 \mathrm{mg} / \mathrm{mL}$, the mean lesion volume (as measured by mpMRI) decreased, as did the prostate specific antigen (PSA) density. ITP SPP treatment was found to be well tolerated with no safety concerns at the $15 \mathrm{mg} / \mathrm{mL}$ concentration and provided preliminary evidence of activity.

A second clinical trial is underway in patients with localized prostate cancer (Gleason $\geq 6$ ) utilizing multiple injections over a 16-week period prior to prostatectomy (NCT04221828) to further evaluate safety, efficacy, and immune response. The lack of systemic toxicity and minimal local irritation observed following ITP SPP treatment in the first prostate cancer study may allow for multiple staged injections in future studies, the timing of which could be triggered by rising PSA levels during routine SOC. Persistent paclitaxel within the prostate may act as an adjuvant "sensitizer" to radiation therapy or focal ablative therapies such as high-intensity focused ultrasound (HIFU).

\section{Pancreatic cancer}

Pancreatic cancer demonstrates a limited response to systemic cancer therapy. This may be due in part to the aggressive nature of tumor cells and to the desmoplastic, fibrotic stroma associated with pancreatic cancer, which blocks transport and diffusion of small molecules [20, 21]. The dense stroma also creates damaged or "leaky" blood vessels causing poor drainage of lymphatic and vascular fluids. Excess fluid increases interstitial fluid pressures, thus compressing vessels and decreasing micro-vessel density [20, 22]. The poorly vascularized stroma creates a hypoxic environment, suppressing the immune response and forming a barrier to systemic drug delivery. Surgical resection of the tumor, when possible, is currently the only curative therapy. Unfortunately, surgical resection is often not possible due to anatomical complications when the patient initially presents for medical care.

IT SPP via endoscopic ultrasound-guided fine needle injection (EUS-FNI) has shown promise in a clinical trial of patients with locally advanced pancreatic cancer (LAPC) (NCT03077685, [23]). Subjects with non-resectable LAPC lesions with a diameter of $1.5-6 \mathrm{~cm}$ were directly injected with SPP via EUS-FNI in a $3+3$ dose-escalation design at 6,10 , and $15 \mathrm{mg} / \mathrm{mL}$ in volumes up to $20 \%$ of the tumor (not exceeding $5 \mathrm{~mL}$ ). Subjects in the second phase of the study received two SPP injections 4 weeks apart at $15 \mathrm{mg} /$ $\mathrm{mL}$. An additional cohort of subjects is now open to recruitment, where up to four injections will be given via EUSFNI one month apart. Injections are performed through a 22-gauge needle in a fan-like pattern to ensure drug dispersion throughout the tumor.

In the 29 subjects to date who have received one $(n=7)$ or $2(n=22)$ injections of SPP at $15 \mathrm{mg} / \mathrm{ml}$, there have been no cases of pancreatitis, no SAEs definitely related to drug, and no clinically significant laboratory abnormalities. There have been no adverse events that were considered to be dose-limiting. Paclitaxel in the plasma was detected at levels below $10 \mathrm{ng} / \mathrm{mL}$ during the first $24 \mathrm{~h}$ after IT SPP administration, returning to undetectable levels by 4 weeks [23, 24].

RECIST 1.1 evaluation of the tumor volumes in the twoinjection group of subjects demonstrated stable disease in two of eleven subjects at 6 months (Fig. 8a), progressive disease in two subjects, and partial or full responses in seven subjects. Thus far, one subject (04001) in the second phase who received 2 injections was down-staged during study and underwent surgical resection of tumor resulting in $\mathrm{R} 0$ and LN0 outcomes [23], and other subjects are under evaluation for reassessment of surgical status.

\section{Pancreatic mucinous cysts}

Pancreatic mucinous cystic neoplasms (MCNs) and intraductal papillary mucinous neoplasms (IPMNs) have significant potential to undergo malignant transformation into pancreatic cancer [26]. These cysts are at high risk for progression and often require precautionary pancreatectomy, a procedure associated with high morbidity and potential for cyst recurrence. Ethanol ablation followed by paclitaxel 
Fig. 8 Change in tumor volume of locally advanced pancreatic cancer following two IT injections of submicron particle paclitaxel (a) and mucinous pancreatic cysts in subjects following a single injection of submicron particle paclitaxel via EUS-FNI (b). No subject developed clinically significant local or systemic toxicity from the drug or injection(s) [23, 25]

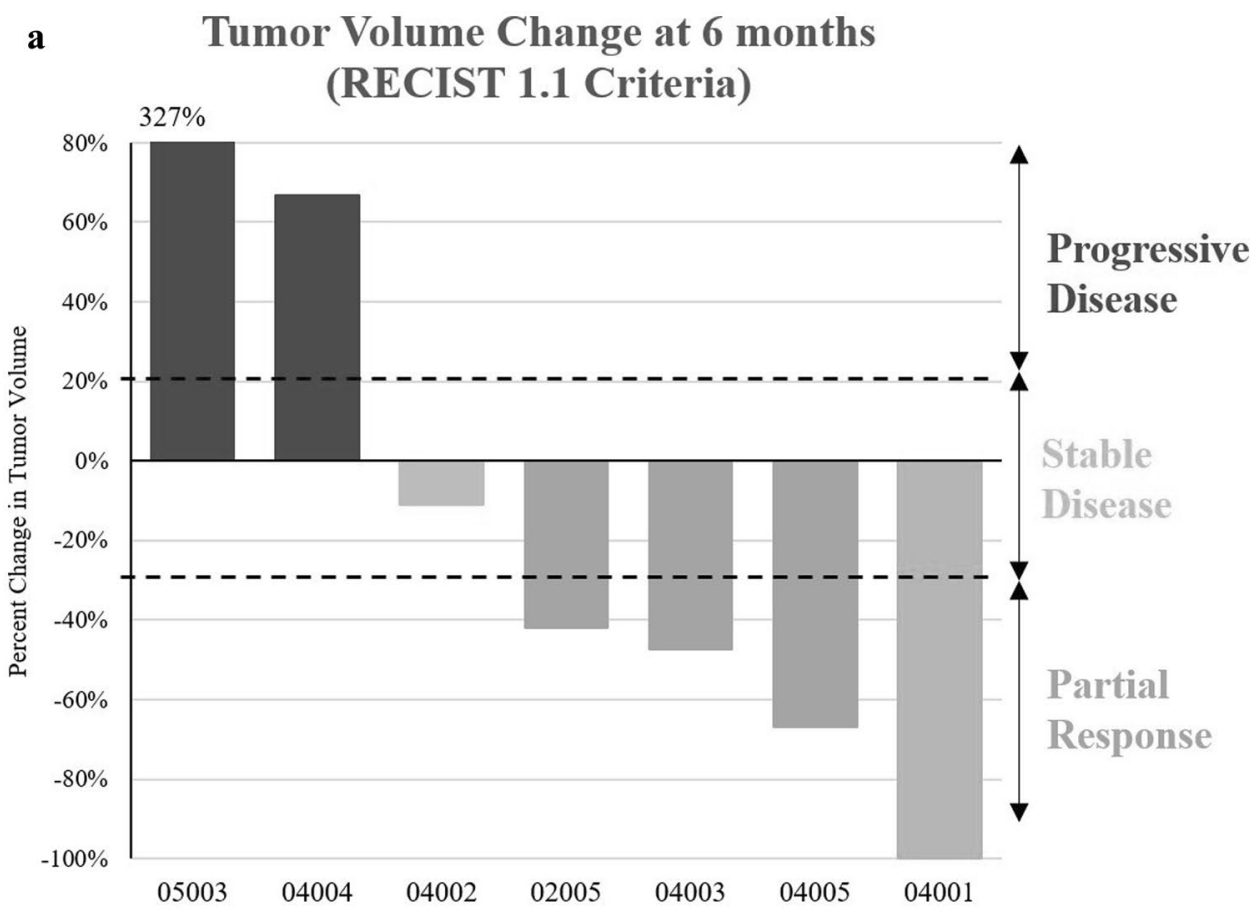

Radiographic analysis dose confirmation phase two injections $(n=7)$

b

Cyst Volume Change at 6 months

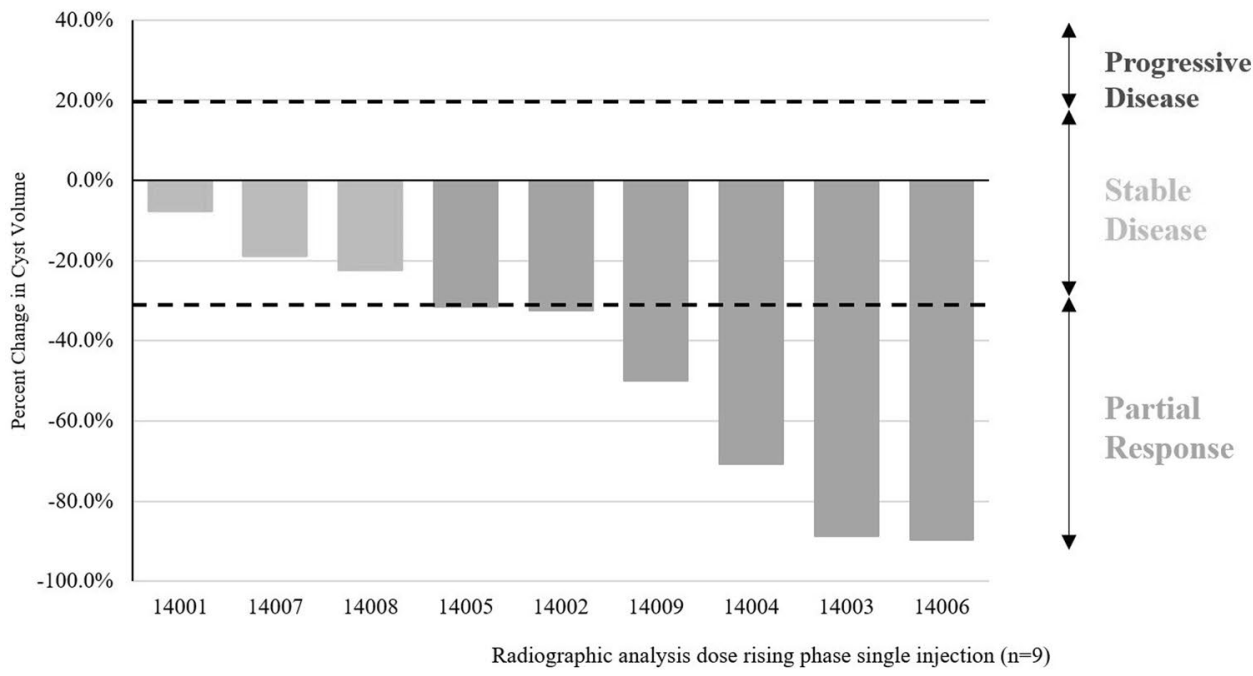

administration via EUS-FNI is a minimally invasive technique that has shown benefit in the treatment of cystic lesions [27, 28].

A trial evaluating intracystic administration of SPP by EUS-FNI into mucinous pancreatic cysts has completed (NCT03188991). This trial was similar in design and dose to the pancreatic cancer trial, with a dose escalation phase (SPP at 6, 10, and $15 \mathrm{mg} / \mathrm{mL}$ at volumes sufficient to fill the cyst, at least equal to the amount of cyst fluid aspirated) followed by a second phase in which subjects received two administrations of SPP at $15 \mathrm{mg} / \mathrm{mL}$ administered 12 weeks apart. Patients were followed for 6 months after the first injection. Nineteen patients were enrolled in the study. Nine patients have completed the dose-rising phase of the study and eight have completed the second (two-injection) phase. No clinically significant local toxicity or significant laboratory abnormalities from SPP have been observed. Plasma paclitaxel concentration did not exceed $3.5 \mathrm{ng} / \mathrm{mL}$ at any timepoint measured and fell below $1 \mathrm{ng} / \mathrm{mL}$ by Week 2 , supporting retention of paclitaxel particles within the pancreatic cyst [25]. Currently, cyst volumes in eight of the nine evaluable subjects in the dose escalation cohorts remain reduced at Month 6 (Fig. 8b). 


\section{Mechanism of action}

Paclitaxel's primary cytotoxic mechanism acts by inhibiting tubulin depolymerization, stalling the cell cycle in the $\mathrm{G} 2 / \mathrm{M}$ phase, interfering with tumor cell replication and resulting in tumor cell death [29] which can produce both apoptotic as well as necroptotic cell death. Necroptosis (necrosis) is a drug-and dose-dependent mechanism of tumor cell destruction achieved by the persistence of relatively high levels of chemotherapy in the TME. In contrast to apoptosis, which often includes collapse and contraction of tumor cells, necroptosis is associated with loss of tumor cell membrane integrity, exposing tumorspecific antigens to immune surveillance. This process can stimulate a robust response of the adaptive immune system against the tumor-specific antigens that otherwise would remain "unseen" by immune effector cells, enhancing immune effector cell infiltration into the TME [30-32]. Paclitaxel was shown to induce necroptotic tumor cell death following exposure to high drug concentrations [33]. The histologic patterns of tumor cell death following local administration of SPP are reminiscent of those associated with necroptotic tumor cell death $[7,30]$. Thus, SPP-induced cell death appears to be a continuum between apoptosis and necroptosis depending on drug concentration and duration of tumor cell exposure [31, 34, 35].

\section{Summary and conclusions}

Local administration of SPP continuously exposes primary tumors to therapeutic levels of paclitaxel for several weeks. Continuous exposure of solid carcinomas to tumoricidal levels of paclitaxel was shown in preclinical studies and early, limited clinical trials to provide clinical benefits with minimal local or systemic toxicity. Paclitaxel-induced neutropenia and other systemic toxicities are related to the duration and extent of systemic exposure to paclitaxel above a threshold plasma concentration of $\geq 40 \mathrm{ng} /$ $\mathrm{mL}$ [16]. In contrast, plasma paclitaxel concentrations observed after injecting SPP into the lobe of the prostate had $C_{\max }$ values of 19 to $20 \mathrm{ng} / \mathrm{mL}$ recorded at the $1-\mathrm{h}$ timepoint. By comparison, a standard IV dose of paclitaxel of $175 \mathrm{mg} / \mathrm{m}^{2}$ administered over $3 \mathrm{~h}$ results in a $C_{\max }$ of $3,650 \mathrm{ng} / \mathrm{mL}$. This is approximately $192 \times$ higher than the mean paclitaxel concentration following SPP injection in a dose of $15 \mathrm{mg} / \mathrm{ml}$ in a volume $20 \%$ of the prostate lobe $1 \mathrm{~h}$ after injection. In addition, measurements of plasma paclitaxel levels following IT SPP in pancreatic cancer trials and IP SPP in peritoneal cancer trials remained well below the $40 \mathrm{ng} / \mathrm{mL}$ toxicity threshold. These low levels of plasma paclitaxel following local administration of SPP may explain the absence of clinically significant toxicity seen thus far in various clinical trials (Table 1) involving more than 150 subjects.

SPP administration may complement treatment of metastatic disease with traditional therapies such as chemotherapy, targeted therapy, immunotherapy, and radiation. Paclitaxel affects many aspects of immune function, including lymphocyte recruitment and activation as well as production of immunoenhancing cytokines, including IL-12 [34-37], IFN $\gamma$ and TNF $\alpha$, which may augment the antitumor activity of immunotherapies [38]. Paclitaxel was shown to enhance immune responses including increased concentrations of tumor-infiltrating lymphocytes that successfully eradicate malignant cells [39-41]. Paclitaxel may be a particularly strong immunostimulant, as it is able to both activate $\mathrm{CD} 8+\mathrm{T}$ cells and reduce immunosuppressive cells, such as regulatory T cells [34-36, 42-44] and myeloid-derived suppressor cells (MDSC) [30, 36, 45]. To maximize tumoricidal effects, it has been hypothesized that the immune system can be primed with systemic chemotherapy ahead of immunotherapy to re-instate or enhance immunosurveillance [37, 39]. The priming effect of locally administered SPP may not only provide tumoricidal activity but also induce immunemediated effects [37, 46-49]. The persistence of paclitaxel in the tumor site may expose slowly replicating tumor cells to tumoricidal drug levels. This chronic state of cell death could affect the immune system by (1) increasing the opportunity for tumor-associated antigens to be released and recognized by the immune system, (2) decreasing the number of cells able to send an immunosuppressive signal, and (3) attracting immune and phagocytic cells to remove tumor cell debris. While a combination of systemic chemotherapy and immunotherapy has the potential to increase efficacy [46], these regimens are also additive to systemic toxicity. Local administration of SPP has the potential to synergize with immunotherapy without added toxic exposure to nontarget organs.

Injection of SPP into a primary tumor appears to facilitate an immune response which may improve clinical benefits reminiscent of those reported in studies where radiation and ablation were used to create an "inflamed" TME that synergizes with immune therapy [47-56]. Preliminary studies of SPD injected into syngeneic Renca tumors also produced reduction in tumor size with associated increases in effector immune cell concentrations [57]. Potential therapeutic opportunities for administration of SPP to treat carcinomas include (1) inhalation of nebulized particles and/or direct injection of tumors obstructing airways to treat pulmonary cancers; 2) IP SPP to treat peritoneal metastasis, ovarian, hepatic, and other gastrointestinal cancers; (3) direct injection via TRUS-FNI to achieve reduction of prostate cancer or delay progression, allowing for delay or prevention of 
prostatectomy or whole gland therapy; (4) direct injection via EUS-FNI into pancreatic cancer; and (5) intracystic injection of pancreatic mucinous cysts to prevent partial pancreatectomy. The broad antitumor effects and safety observed preclinically and clinically, and the apparent stimulation of the immune system following SPP treatment support additional preclinical and clinical investigations with this drug.

\section{Open access}

This article is distributed under the terms of the Creative Commons Attribution 4.0 International License (https://creativecommons.org/licenses/by/4.0/), which permits unrestricted use, distribution, and reproduction in any medium, provided you give appropriate credit to the original author(s) and the source, provide a link to the Creative Commons license, and indicate if changes were made.

Acknowledgments NanoPac ${ }^{\circledR}$ and NanoDoce $₫$ are registered trademarks of NanOlogy, LLC. The authors would like to thank CritiTech, Inc. for investigational product supply; NanOlogy, LLC. for funding the preclinical and clinical trials; Louis Lazo Radulovic and Mark Milad for pharmacokinetic consulting; and Samantha Mauro, Karan Dewnani, Kainoa Peterson, David Jones, Alexis Voss, Lauren Hylle, and Sara Dafoe for their assistance in document preparation.

Funding This research was funded by NanOlogy, LLC.

Data availability The datasets generated during and/or analyzed during the current study are available from the corresponding author on reasonable request.

\section{Compliance with ethical standards}

Conflict of interest The following authors report holding a consultant/ advisory role, having stock ownership, or receiving funding from $\mathrm{Na}-$ nOlogy, S.V., H.M., M.B., E.W., M.I., A.W., J.V., A.M., S.C., P.D., and G.S.d.

Ethical approval All institutional and national guidelines for the care and use of laboratory animals were followed.

Investigational Review Boards for all participating clinical sites provided approval for protocol and informed consents for subjects in accordance with the Code of Federal Regulations and local requirements.

Informed consent All procedures followed were in accordance with the ethical standards of the responsible committee on human experimentation (institutional and national) and with the Helsinki Declaration of 1975 , as revised in 2000 (5). Informed consent was obtained from all patients for being included in the study.

Open Access This article is licensed under a Creative Commons Attribution 4.0 International License, which permits use, sharing, adaptation, distribution and reproduction in any medium or format, as long as you give appropriate credit to the original author(s) and the source, provide a link to the Creative Commons licence, and indicate if changes were made. The images or other third party material in this article are included in the article's Creative Commons licence, unless indicated otherwise in a credit line to the material. If material is not included in the article's Creative Commons licence and your intended use is not permitted by statutory regulation or exceeds the permitted use, you will need to obtain permission directly from the copyright holder. To view a copy of this licence, visit http://creativecommons.org/licenses/by/4.0/.

\section{References}

1. Goldberg EP, Hadba AR, Almond BA, Marotta JS. Intratumoral cancer chemotherapy and immunotherapy: opportunities for nonsystemic preoperative drug delivery. J Pharm Pharmacol. 2002;54(2):159-80.

2. Brigger I, Dubernet C, Couvreur P. Nanoparticles in cancer therapy and diagnosis. Adv Drug Deliv Rev. 2002;54(5):631-51. https://doi.org/10.1016/s0169-409x(02)00044-3.

3. Ma P, Mumper RJ. Paclitaxel nano-delivery systems: a comprehensive review. J Nanomed Nanotechnol. 2013;4(2):1000164. https://doi.org/10.4172/2157-7439.1000164.

4. Zhao M, Liu M. New avenues for nanoparticle-related therapies. Nanoscale Res Lett. 2018;13(1):136. https://doi.org/10.1186/ s11671-018-2548-8.

5. Baltezor M, Farthing J, Sittenauer J, Espinosa J, Campbell S, McClorey M, Fischer J, Williams M, Clapp G. Taxane particles and their use. U.S. Patent 9,814,685;2017.

6. Verco J, Johnston W, Baltezor M, Kuehl PJ, Gigliotti A, Belinsky SA, Lopez A, Wolff R, Hylle L, diZerega G. Pharmacokinetic profile of inhaled submicron particle paclitaxel $(\operatorname{NanoPac}((\mathrm{R})))$ in a rodent model. J Aerosol Med Pulm Drug Deliv. 2019;32(2):99_ 109. https://doi.org/10.1089/jamp.2018.1467.

7. Verco J, Johnston W, Frost M, Baltezor M, Kuehl PJ, Lopez A, Gigliotti A, Belinsky SA, Wolff R, diZerega G. Inhaled submicron particle paclitaxel (NanoPac) induces tumor regression and immune cell infiltration in an orthotopic athymic nude rat model of non-small cell lung cancer. J Aerosol Med Pulm Drug Deliv. 2019. https://doi.org/10.1089/jamp.2018.1517.

8. Maulhardt HA, Hylle L, Frost MV, Tornio A, Dafoe S, Drummond L, Quinn DI, Kamat AM, diZerega GS. Local injection of submicron particle docetaxel is associated with tumor eradication, reduced systemic toxicity and an immunologic response in urooncologic xenografts. Cancers. 2019;11(4):577. https://doi.org/ 10.3390/cancers 11040577 .

9. Hohenforst-Schmidt W, Zarogoulidis P, Darwiche K, Vogl T, Goldberg EP, Huang H, Simoff M, Li Q, Browning R, Turner FJ, Le Pivert P, Spyratos D, Zarogoulidis K, Celikoglu SI, Celikoglu F, Brachmann J. Intratumoral chemotherapy for lung cancer: re-challenge current targeted therapies. Drug Des Devel Ther. 2013;7:571-83. https://doi.org/10.2147/DDDT.S46393.

10. Kuzmov A, Minko T. Nanotechnology approaches for inhalation treatment of lung diseases. J Control Release. 2015;219:500-18. https://doi.org/10.1016/j.jconrel.2015.07.024.

11. Rosiere R, Van Woensel M, Gelbcke M, Mathieu V, Hecq J, Mathivet T, Vermeersch M, Van Antwerpen P, Amighi K, Wauthoz N. New Folate-Grafted Chitosan Derivative To Improve Delivery of Paclitaxel-Loaded Solid Lipid Nanoparticles for Lung Tumor Therapy by Inhalation. Mol Pharm. 2018;15(3):899-910. https://doi.org/10.1021/acs.molpharmaceut.7b00846.

12. Miura D, Yoneyama K, Furuhata Y, Shimizu K. Paclitaxel enhances antibody-dependent cell-mediated cytotoxicity of trastuzumab by rapid recruitment of natural killer cells in HER2positive breast cancer. J Nippon Med Sch. 2014;81(4):211-20.

13. Baltezor M, diZerega G, Decedue C, Campbell S, McClorey M, Maulhardt H. Treatment of kidney tumors by intratumoral injection of taxane particles. US 2019/0365699;2019. 
14. Baltezor M, diZerega G, Decedue C, Campbell S, McClorey M. Methods for solid tumor treatment. U.S. Patent 10,391,090;2019.

15. Williamson SK, Johnson GA, Maulhardt HA, Moore KM, McMeekin DS, Schulz TK, Reed GA, Roby KF, Mackay CB, Smith HJ, Weir SJ, Wick JA, Markman M, diZerega GS, Baltezor MJ, Espinosa J, Decedue CJ. A phase I study of intraperitoneal nanoparticulate paclitaxel $(\operatorname{Nanotax}(\mathrm{R}))$ in patients with peritoneal malignancies. Cancer Chemother Pharmacol. 2015;75(5):107587. https://doi.org/10.1007/s00280-015-2737-4.

16. Rowinsky EK, Jiroutek M, Bonomi P, Johnson D, Baker SD. Paclitaxel steady-state plasma concentration as a determinant of disease outcome and toxicity in lung cancer patients treated with paclitaxel and cisplatin. Clin Cancer Res. 1999;5(4):767-74.

17. Cristea MC, Frankel P, Synold T, Rivkin S, Lim D, Chung V, Chao J, Wakabayashi M, Paz B, Han E, Lin P, Leong L, Hakim A, Carroll M, Prakash N, Dellinger T, Park M, Morgan RJ. A phase I trial of intraperitoneal nab-paclitaxel in the treatment of advanced malignancies primarily confined to the peritoneal cavity. Cancer Chemother Pharmacol. 2019;83:589-98. https://doi.org/10.1007/ s00280-019-03767-9.

18. Mullany S, Miller D, Robison K, Levinson K, Lee Y, Yamada SD, Walker J, Markman M, Marin A, Mast P, diZerega G. Phase II study of intraperitoneal submicron particle paclitaxel (SPP) plus IV carboplatin and paclitaxel in patients with epithelial ovarian cancersurgery. Gynecologic Oncology Reports. 2020;34:100627. https://doi.org/10.1016/j.gore.2020.100627.

19. Ohtsu T, Sasaki Y, Tamura T, Miyata Y, Nakanomyo H, Nishiwaki Y, Saijo N. Clinical pharmacokinetics and pharmacodynamics of paclitaxel: a 3-hour infusion versus a 24-hour infusion. Clin Cancer Res. 1995;1(6):599-606.

20. Heinemann V, Reni M, Ychou M, Richel DJ, Macarulla T, Ducreux M. Tumour-stroma interactions in pancreatic ductal adenocarcinoma: rationale and current evidence for new therapeutic strategies. Cancer Treat Rev. 2014;40(1):118-28. https://doi.org/10.1016/j.ctrv.2013.04.004.

21. Smyth EN, Bapat B, Ball DE, Andre T, Kaye JA. Metastatic pancreatic adenocarcinoma treatment patterns, health care resource use, and outcomes in france and the United Kingdom between 2009 and 2012: a retrospective study. Clin Ther. 2015;37(6):130116. https://doi.org/10.1016/j.clinthera.2015.03.016.

22. Provenzano PP, Cuevas C, Chang AE, Goel VK, Von Hoff DD, Hingorani SR. Enzymatic targeting of the stroma ablates physical barriers to treatment of pancreatic ductal adenocarcinoma. Cancer Cell. 2012;21(3):418-29. https://doi.org/10.1016/j. ccr.2012.01.007.

23. Sharma N, Othman M, Mendoza-Ladd A, Verco S, Verco J, diZerega G, Lo S. EUS-guided injection of intratumoral submicron particle paclitaxel (SPP) for the treatment of locally advanced pancreatic adenocarcinoma (LAPC): Phase 2 study. American Society for Gastrointestinal Endoscopy: Sa2006;2020.

24. Lo S, Hendifar A, Sharma N, Othman M, Mendoza-Ladd A, Verco $\mathrm{S}$, Verco J, diZerega G. A novel EUS-guided intratumoral delivery of submicron particle paclitaxel (SPP) for the treatment of locally advanced pancreatic cancer (LA-PAC): a prospective safety, tolerability and preliminary efficiency study: 6 . Am J Gastroenterol. 2019;114:S3-4. https://doi.org/10.14309/01.ajg.0000589556. 41054.b3.

25. Othman M, Patel K, Krishna S, Mendoza-Ladd A, Verco S, Verco J, Wendt A, diZerega G. Intracystic Injection of Submicron Particle Paclitaxel (SPP) for the Treatment of Mucinous Pancreatic Cystic Lesions Resulted in Reduction in Cyst Volume, an Interim Report. American Society for Gastrointestinal Endoscopy: Sa1399;2020.

26. Tada M, Kawabe T, Arizumi M, Togawa O, Matsubara S, Yamamoto N, Nakai Y, Sasahira N, Hirano K, Tsujino T, Tateishi K, Isayama $\mathrm{H}$, Toda $\mathrm{N}$, Yoshida $\mathrm{H}$, Omata $\mathrm{M}$. Pancreatic cancer in patients with pancreatic cystic lesions: a prospective study in 197 patients. Clin Gastroenterol Hepatol. 2006;4(10):1265-70. https://doi.org/10.1016/j.cgh.2006.07.013.

27. Oh HC, Seo DW, Song TJ, Moon SH, Park DH, Soo Lee S, Lee SK, Kim MH, Kim J. Endoscopic ultrasonography-guided ethanol lavage with paclitaxel injection treats patients with pancreatic cysts. Gastroenterology. 2011;140(1):172-9. https://doi.org/ 10.1053/j.gastro.2010.10.001.

28. DeWitt JM, Murthy SK, Ardhanari R, DuVall GA, Wallner G, Litka P, Daugherty C, Fowers K. EUS-guided paclitaxel injection as an adjunctive therapy to systemic chemotherapy and concurrent external beam radiation before surgery for localized or locoregional esophageal cancer: a multicenter prospective randomized trial. Gastrointest Endosc. 2017;86(1):140-9. https://doi.org/ 10.1016/j.gie.2016.11.017.

29. Weaver BA. How Taxol/paclitaxel kills cancer cells. Mol Biol Cell. 2014;25(18):2677-81. https://doi.org/10.1091/mbc. E14-04-0916.

30. Chen D, Yu J. Zhang L (2016) Necroptosis: an alternative cell death program defending against cancer. Biochim Biophys Acta. 1865;2:228-36. https://doi.org/10.1016/j.bbcan.2016.03.003.

31. Bracci L, Schiavoni G, Sistigu A, Belardelli F. Immune-based mechanisms of cytotoxic chemotherapy: implications for the design of novel and rationale-based combined treatments against cancer. Cell Death Differ. 2014;21(1):15-25. https://doi.org/ 10.1038/cdd.2013.67.

32. Sancho D, Joffre OP, Keller AM, Rogers NC, Martinez D, HernanzFalcon P, Rosewell I, Reis e Sousa C. Identification of a dendritic cell receptor that couples sensing of necrosis to immunity. Nature. 2009;458(7240):899-903. https://doi.org/10.1038/nature07750.

33. Jang MS, Lee SJ, Kang NS, Kim E. Cooperative phosphorylation of FADD by Aur-A and Plk1 in response to taxol triggers both apoptotic and necrotic cell death. Cancer Res. 2011;71(23):720715. https://doi.org/10.1158/0008-5472.CAN-11-0760.

34. Soliman HH. nab-Paclitaxel as a potential partner with checkpoint inhibitors in solid tumors. Onco Targets Ther. 2017;10:101-12. https://doi.org/10.2147/OTT.S122974.

35. Javeed A, Ashraf M, Riaz A, Ghafoor A, Afzal S, Mukhtar MM. Paclitaxel and immune system. Eur J Pharm Sci. 2009;38(4):28390. https://doi.org/10.1016/j.ejps.2009.08.009.

36. Zheng H, Zeltsman M, Zauderer MG, Eguchi T, Vaghjiani RG, Adusumilli PS. Chemotherapy-induced immunomodulation in non-small-cell lung cancer: a rationale for combination chemoimmunotherapy. Immunotherapy. 2017;9(11):913-27. https://doi.org/ 10.2217/imt-2017-0052.

37. Conway EM, Pikor LA, Kung SH, Hamilton MJ, Lam S, Lam WL, Bennewith KL. Macrophages, inflammation, and lung cancer. Am J Respir Crit Care Med. 2016;193(2):116-30. https://doi.org/ 10.1164/rccm.201508-1545CI.

38. Chan OT, Yang LX. The immunological effects of taxanes. Cancer Immunol Immunother. 2000;49(4-5):181-5.

39. Demaria S, Volm MD, Shapiro RL, Yee HT, Oratz R, Formenti SC, Muggia F, Symmans WF. Development of tumor-infiltrating lymphocytes in breast cancer after neoadjuvant paclitaxel chemotherapy. Clin Cancer Res. 2001;7(10):3025-30.

40. Moschetta M, Pretto F, Berndt A, Galler K, Richter P, Bassi A, Oliva P, Micotti E, Valbusa G, Schwager K, Kaspar M, Trachsel E, Kosmehl H, Bani MR, Neri D, Giavazzi R. Paclitaxel enhances therapeutic efficacy of the F8-IL2 immunocytokine to EDA-fibronectin-positive metastatic human melanoma xenografts. Cancer Res. 2012;72(7):1814-24. https://doi.org/10.1158/00085472.CAN-11-1919.

41. Pasche N, Wulhfard S, Pretto F, Carugati E, Neri D. The antibody-based delivery of interleukin-12 to the tumor neovasculature eradicates murine models of cancer in combination with 
paclitaxel. Clin Cancer Res. 2012;18(15):4092-103. https://doi.org/ 10.1158/1078-0432.CCR-12-0282.

42. Vicari AP, Luu R, Zhang N, Patel S, Makinen SR, Hanson DC, Weeratna RD, Krieg AM. Paclitaxel reduces regulatory T cell numbers and inhibitory function and enhances the anti-tumor effects of the TLR9 agonist PF-3512676 in the mouse. Cancer Immunol Immunother. 2009;58(4):615-28. https://doi.org/ 10.1007/s00262-008-0586-2.

43. Chen DS, Mellman I. Oncology meets immunology: the cancerimmunity cycle. Immunity. 2013;39(1):1-10. https://doi.org/ 10.1016/j.immuni.2013.07.012.

44. Chen G, Emens LA. Chemoimmunotherapy: reengineering tumor immunity. Cancer Immunol Immunother. 2013;62(2):203-16. https://doi.org/10.1007/s00262-012-1388-0.

45. Galluzzi L, Senovilla L, Zitvogel L, Kroemer G. The secret ally: immunostimulation by anticancer drugs. Nat Rev Drug Discov. 2012;11(3):215-33. https://doi.org/10.1038/nrd3626.

46. Champiat S, Tselikas L, Farhane S, Raoult T, Texier M, Lanoy E, Massard C, Robert C, Ammari S, De Baere T, Marabelle A. Intratumoral immunotherapy: from trial design to clinical practice. Clin Cancer Res. 2020. https://doi.org/10.1158/1078-0432. CCR-20-0473.

47. Waitz R, Solomon SB, Petre EN, Trumble AE, Fasso M, Norton L, Allison JP. Potent induction of tumor immunity by combining tumor cryoablation with anti-CTLA-4 therapy. Cancer Res. 2012;72(2):430-9. https://doi.org/10.1158/0008-5472. CAN-11-1782.

48. Rodriguez-Ruiz ME, Vanpouille-Box C, Melero I, Formenti SC, Demaria S. Immunological mechanisms responsible for radiationinduced abscopal effect. Trends Immunol. 2018;39(8):644-55. https://doi.org/10.1016/j.it.2018.06.001.

49. Liu Y, Dong Y, Kong L, Shi F, Zhu H, Yu J. Abscopal effect of radiotherapy combined with immune checkpoint inhibitors. J Hematol Oncol. 2018;11(1):104. https://doi.org/10.1186/s13045018-0647-8.

50. Park SS, Dong H, Liu X, Harrington SM, Krco CJ, Grams MP, Mansfield AS, Furutani KM, Olivier KR, Kwon ED. PD-1 restrains radiotherapy-induced abscopal effect. Cancer Immunol Res. 2015;3(6):610-9. https://doi.org/10.1158/2326-6066. CIR-14-0138.

51. Menon H, Chen D, Ramapriyan R, Verma V, Barsoumian HB, Cushman TR, Younes AI, Cortez MA, Erasmus JJ, de Groot P,
Carter BW, Hong DS, Glitza IC, Ferrarotto R, Altan M, Diab A, Chun SG, Heymach JV, Tang C, Nguyen QN, Welsh JW. Influence of low-dose radiation on abscopal responses in patients receiving high-dose radiation and immunotherapy. J Immunother Cancer. 2019;7(1):237. https://doi.org/10.1186/s40425-019-0718-6.

52. Lin AJ, Roach M, Bradley J, Robinson C. Combining stereotactic body radiation therapy with immunotherapy: current data and future directions. Trans1 Lung Cancer Res. 2019;8(1):107-15. https://doi.org/10.21037/tlcr.2018.08.16.

53. Walshaw RC, Honeychurch J, Illidge TM. Stereotactic ablative radiotherapy and immunotherapy combinations: turning the future into systemic therapy? Br J Radiol. 2016;89(1066):20160472. https://doi.org/10.1259/bjr.20160472.

54. Chicas-Sett R, Morales-Orue I, Castilla-Martinez J, Zafra-Martin J, Kannemann A, Blanco J, Lloret M, Lara PC. Stereotactic ablative radiotherapy combined with immune checkpoint inhibitors reboots the immune response assisted by immunotherapy in metastatic lung cancer: a systematic review. Int J Mol Sci. 2019;20(9):2173. https://doi.org/10.3390/ijms20092173.

55. Britschgi C, Riesterer O, Burger IA, Guckenberger M, CurioniFontecedro A. Report of an abscopal effect induced by stereotactic body radiotherapy and nivolumab in a patient with metastatic nonsmall cell lung cancer. Radiat Oncol. 2018;13(1):102. https://doi. org/10.1186/s13014-018-1049-3.

56. Ngwa W, Irabor OC, Schoenfeld JD, Hesser J, Demaria S, Formenti SC. Using immunotherapy to boost the abscopal effect. Nat Rev Cancer. 2018;18(5):313-22. https://doi.org/10.1038/ nrc.2018.6.

57. Maulhardt HA, Marin AM, diZerega GS. Intratumoral submicron particle docetaxel inhibits syngeneic Renca renal cancer growth and increases CD4+, CD8+, and Treg levels in peripheral blood. Invest New Drugs. 2020. https://doi.org/10.1007/s10637-02000922-5.

Publisher's Note Springer Nature remains neutral with regard to jurisdictional claims in published maps and institutional affiliations. 